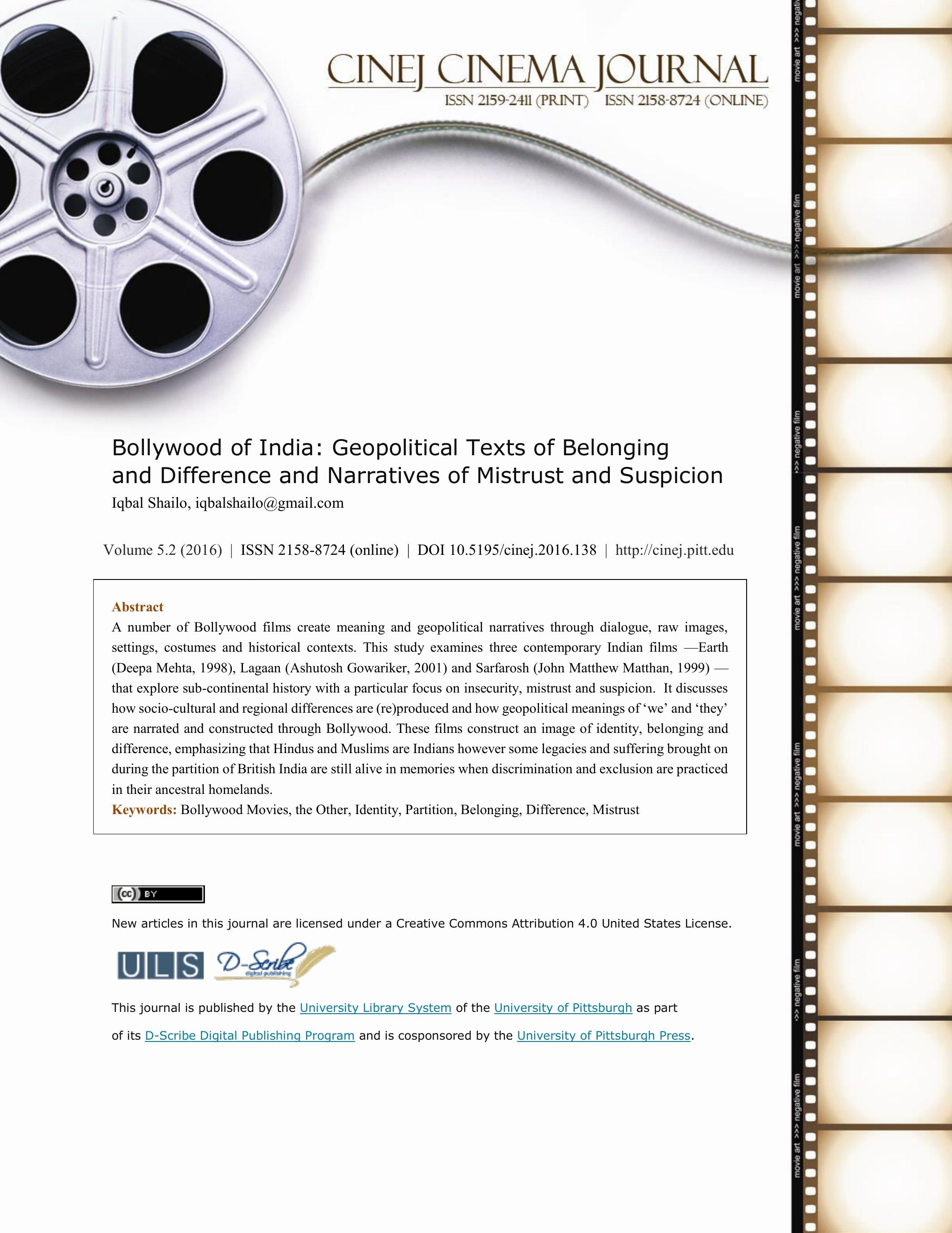




\section{Bollywood of India: Geopolitical Texts of Belonging and Difference and Narratives of Mistrust and Suspicion}

\section{Iqbal Shailo}

\section{Introduction}

Bollywood can be understood in terms of geopolitical narratives and geo-historical texts, and has played a pioneering role in constructing discourses with political implications. The study discusses how meaning is derived and understood from images and narratives contained in films and how they work to construct discourses on identity, belonging, difference and mistrust. It examines three contemporary Indian films-Earth, Lagaan and Sarfarosh - which explore subcontinental history with a particular focus on insecurity, mistrust, togetherness, difference and identity. Though territorial boundaries or the constructed borders of the Sub-continent isolated people from each other films still nourish the bonds they once shared for centuries. These three films discuss how socio-cultural and regional differences are (re)produced and how the meaning of community, mistrust, difference and transborder relations are understood. The characters, dialogue, debates and discussion in these movies reflect discourses of togetherness, differences, mistrust and suspicion.

The study is structured as follows: First, it briefly discusses the gradual development of Bollywood movies despite various challenges faced by the industry from governments and other sectors at various periods. Second, it explains the multifaceted relationships between the characters of Earth, Lagaan and Sarfarosh, as well as historic values and the way in which dialogues and debates between characters work as a source of political discourses in nation building, togetherness, difference and mistrust. Third, it highlights how minorities are marginalized, demonized and demeaned in the narrative of commercial Hindi films. Fourth, the study explains 
that some Bollywood movies in the region are connected with a formation of geopolitical imaginations in order to provide an understanding of culture, rituals, danger, identity and messages of reconciliation. It concludes with a suggestion that the aforesaid movies, while supportive of India's integrity and nationalistic outlooks, somehow do not reflect the core secular values of India that Gandhi used to believe or messages disseminated over decades to bring together his nation.

\section{Bollywood Movies: Challenges from within}

The name "Bollywood" based in Mumbai, a business hub of India, is a combination of two words: "Bo" from Bombay (the previous name of Mumbai) and "llywood" from Hollywood. The term Bollywood was incepted in the 1970s when India's film production industry surpassed Hollywood to become a world leader in terms of film production. Bollywood along with other regional film industries produced more than one thousand movies annually. The first Indian film, titled Raja Harishchandra (King Harishchandra) was screened in 1914 during World War I and it was the first silent feature in British India. ${ }^{1}$ The first Indian film with sound was Alam Ara (The Light of the World) directed by Ardeshir Irani in 1931, which had a major commercial success.

In a South Asian context, film and documentaries are used to explore identity, nation formation, togetherness, faith, culture, religious taboo and especially structures of national identity. For example, certain Bollywood movies created by the Indian film industry in Mumbai have inspired the masses to better understand themselves; they have also widened the gap between Hindu and Muslim identity by narrating their faiths (i.e., Muslims and Hindus/We and They). A few movies released in the 1980s, 1990s and 2000s disseminate specific massages pertaining to identity, threat, suspicion and security. Some of these include: Mission Kashmir (2000), Refugee

CINEJ Cinema Journal Bollywood of India: Geopolitical Texts of Belonging and Difference and Narratives of Mistrust and Suspicion Volume 5.2(2016) | ISSN 2158-8724 (online) | DOI 10.5195/cinej.2016.138 | http://cinej.pitt.edu 
(2000), Bombay (1995), Roja (1992), Border (1997), Lakshya (Kargil War) (2003), Prem Pujari [1965 War] (1965), Vijeta [1971 War] (1982).

Of late, Indian Hindi movies have merged into mainstream cinema worldwide, and have even captured the attention of the American Academy Awards (also known as the Oscars). Among others, Monsoon Wedding, Bend It Like Beckham, Bollywood/Hollywood, Fire, Earth, Water and My Name is Khan have captured the imagination of western people. Indian cinema has recently become a focus of study and analysis by western critics and South Asian movie analysts. "For decades, the Hindi popular cinema has had an appeal beyond South Asia. It has an enthusiastic following in the so-called South Asian diaspora, the communities of South Asian origin residing all over the world, including the West." ${ }^{2}$

Since the 1990s the Indian film industry has undergone a massive change due to the gradual rise of the urban middle class. Bollywood movies have fascinated Indians and the South Asian diaspora in more than sixty countries. ${ }^{3}$ The entire film industry of India earned about 14.6 million rupees from overseas, in 1998 that figure rose to 4 billion rupees, and by 2003 it reached close to 7 billion. ${ }^{4}$ Indian cinema has exceeded every other film industry in the world with respect to audience. Since the 1990s it has captured the attention of academic enquiry in India and abroad.

The month of May in 1998 is considered an important time in the history of Indian film as this is when the government recognized it as an industry. It achieved formal industry status three years later in $2001 .^{5}$ The government of India has been realizing the influence of Indian cinema overseas; Non-Resident Indians (NRI) and their cultures around the world are inspired especially by the glamour of Indian girls, romance, melodrama, comedy, horror and folk-tale dances. 
The content of commercial Indian movies is sometimes borrowed from Hollywood stories, dialogues and settings. As film is a reflection of a society's advancement and growth, Indian movies inadequately reflect the suffering and poor living conditions of populations in the country. The real Indian filmic masala (genres) are hybrid versions of imitations, and some of them, being far from reality, are almost Utopian. They are "best considered as hybrid forms, sometimes borrowing from one another, sometimes quoting each other and frequently blending together." 6

\section{Earth, Lagaan and Sarfarosh: Narratives of Belonging, Difference and Mistrust}

India's main initiative is to build a secular society accommodating various races and ethnic groups including a large Muslim minority. Earth revisited the unspeakable suffering of Muslims, Hindus and Sikhs who left their homeland for a newly constructed country that triggered violence, killing, arson, pillage and rape, which resulted in a combined effort to find unity and strength for their survival. On the other hand, Lagaan is concerned with past events during colonial rule and the long-desired partition of the Sub-continent. It also provides a re-interpretation of British torture and brutal rule in the colonized Sub-continent, which gradually roused sentiments of independence and Indian nationalism. Lichtner and Bandyopadhya have rightly noted that "one film (Earth) shuns the conventions of Bollywood cinema while the other (Lagaan) embraces them; one promotes an openly left-wing political agenda and interpretation of history while the other oscillates between Marxist overtones and a very conservative image of society." 7

Deepa Mehta’s Earth (1998), Ashutosh Gowariker's Lagaan (Tax): Once Upon a Time in India (2001) and John Matthew Matthan's Sarfarosh (1999) are primary examples of how movies portray Indian nationhood, identity crisis, mistrust, disbelief, terror and suspicion. These

CINEJ Cinema Journal Bollywood of India: Geopolitical Texts of Belonging and Difference and Narratives of Mistrust and Suspicion

Volume 5.2(2016) ｜ ISSN 2158-8724 (online) ｜ DOI 10.5195/cinej.2016.138 | http://cinej.pitt.edu 
three movies reflect a more inclusive Indian society by discussing past events through the personal experience of contemporary characters in such a way that the audience garners a better understanding of India's past and colonial legacies while constructing discourses of unity, brotherhood, mistrust and differences.

The film Earth begins with Lenny (Maia Sethna) of Earth, a young girl suffering from polio, who narrates the story through her adult voice (Shabana Azmi) recalling "Hindus, Muslims and Sikhs, who had lived together as one entity for centuries started to clamor for pieces of India themselves. The arbitrary line of division the British ... would scar the subcontinent forever." She belongs to a wealthy Parsi family in the area who maintained a neutral position during the partition in 1947. Shanta (Nandita Das), Lenny's Hindu nanny is very popular in the local park as she won the heart of many poor-working class suitors-Hindu, Muslim and Sikh. Shanta responded to one Muslim, Hassan the masseur, and denied the love of another, Dil Nawaz (Aamir Khan), a Muslim ice-candy vendor. When a train laden with the decapitated bodies of Muslim men, women and children arrived in Lahore of Pakistan from Gurdaspur of Indian Punjab, Dil Nawaz found his sister's body. This heinous act by the Sikhs caused Muslims to riot against Sikhs and Hindus. The events of partition caused this group of friends to turn violent against to each other.

Memories, experiences and narratives in Earth bring the audience back to what Gregory calls colonial present, ${ }^{8}$ which is defined as a "painful re-membering, a putting together of the dismembered past to make sense of the trauma of the present." ${ }^{9}$ Deepa Mehta reveals different depictions of partition in India and Pakistan, particularly the violence in Muslim, Hindu, Sikh and Parsi communities. Constructing discourses on nation, nationhood, danger and the "other" as influenced by Subaltern philosophies, Mehta sets her film in Lahore of Pakistan and shows the period before partition to be a place of peace and harmony among and between the different 
communities. But during partition people were the scapegoats of fabricated political tensions and Lahore lost its purity, thereby plunging into civil war.

The young Lenny, the chief protagonist in the film, who witnessed the turmoil resulting from partition during her childhood, discusses the series of events from her perspective as an adult, which allows Mehta to bridge history and present. Earth discusses complex historical issues as well as current politically charged discourses. For example, a sharp debate takes place in Lenny's parents' house between a Sikh guest and a British bureaucrat over the British bringing syphilis back to India_- "there is no syphilis in India until the British came." Here is another example of dialogue that works to create a discourse on nation, identity, danger and the Other.

(Shanta) I have heard before the British gives us independence, they will dig a long canal, one side in independent India and the other side in Pakistan. If they want two countries, that is what they will do, right, Madam? There was no syphilis in India until the British came.

(Sikh) The bastards, they break my country into two pieces and hand it to us and say, "Happy Independence." Millions of Hindus will run from Pakistan and millions of Muslims from Hindustan (India).

(Sikh) I am not going anywhere (i.e., Amritsar of present India), Lahore (of Pakistan) is my home.

(Muslim) Listen, one India is divided; all Muslims left on the wrong side of the division line will have their balls cut off.

(Muslim) We have lived together like brothers for centuries, we share the same language, food, and enemies and they are ready to use it against us Muslims.

(Muslim) Our Holy Quran lies in their [Sikhs] Golden Temple in Amritsar. The Sikhs faith came about to bring Hindus and Muslims close.

(Muslim) Some independence they give us, soaked in our brother's blood.

(Translated from Hindi by the author) 
The film explicitly constructs discourses on identity and a pluralistic society by arguing that contemporary India can easily resolve its many divisions and dogmas rooted in the legacy of partition. "Mehta's premise, critical of the British but also of the Indian elite, is tantamount to advocating better relations between Hindus and Muslims, and therefore between India and Pakistan." ${ }^{10}$ The film itself reflects a discourse on borders and identity by exploring how the formation of a collective identity can be constructed in the post-separation era of India, Pakistan and now Bangladesh. Collective identity, nationalism, boundaries and growing suspicion are the forces behind the political and ethical inclusion and exclusion of people. Political boundary, demarcation and mistrust are important elements in Earth, as the film shows how together the people of the bound communities understand their differences but once this sense of unity is broken due to the demarcation into their land, suspicion and mistrust plague the communities on both sides of the demarcated line.

Lagaan received an Oscar nomination in the category of best foreign language film at the 2002 Academy Awards, and it achieved extraordinary box-office success at home and abroad. In July 2004, it was listed at number 14 among the "50 films to see before you die" in a special program on the UK's TV Channel $4 .{ }^{11}$ The film is based on a cricket tournament in 1893 between the framers of Champaner of India and the army contingent of a local British cantonment. This fictional story is staged in a colonial backdrop of a traditional Indian rural setting in central India, an area presently known as Madhya Pradesh (Central State). The villagers, who are mainly Krishnan (a Hindu god) devotees, are pious and hard-working people who depend on cattle and cultivation. The villagers have been facing a drought over many years. Captain Russell, the head of the cantonment, is a cruel dictator over the locality as well as over the Rajas (kings) of princely states in the surrounding area. 
The British Captain always treats villagers as subjects and curses Rajas, ruling them with an iron fist. He exploits villagers and Rajas and humiliates them considerably. On one occasion during a luncheon he forces Raja Puran Singh to eat meat knowing that he is a vegetarian. When he increases taxes in Champaner, the villagers cry out for leniency. Russell manipulates them into playing a cricket tournament with his team of British soldiers; if his team loses, the province will be exempt from paying taxes for three years. If the villagers lose, they will pay triple the tax (Lagaan). Bhuvan, the hero and young rebel against the British regime, accepts the bet and forms a team comprised of mostly Hindus as well as one Muslim, one Sikh and one Dalit (untouchable). He trains with his fellow teammates and receives help from a sympathetic British lady named Elizabeth, who happens to be Russell's sister. She helps the villagers learn to play cricket, and in the end Russell and his team lose the game and bet. Humiliated, the central British authority leaves the village and withdraws its local cantonment.

The film is a representation of how the colonized triumphed over the colonizers and how the colonized can survive for several years without paying taxes to the raja and the British Empire. The small village is an allegory for India as a whole, where all the characters on Bhuvan's cricket team belong to subaltern classes. Even Bhuvan, the apprentice cricket captain of the village team, selected one Muslim, one Sikh and one Dalit (his name is Kachra meaning literally garbage, rubbish, litter or waste) to be members of the team.

Villagers in the film are the representation of a power-cycle nexus as various degrees of power and domination are at work in Champner in building a strong and strategic alliance "where socially differentiated individuals with different interests and motivations come together as a community to resist the current oppression of the white 'other'." ${ }^{12}$ Here the narratives of identity are vividly presented as villagers demarcating the line between the insiders and the 
outsiders. Bhuvan, the chief protagonist, captures the heart of the village and unites people under his leadership. The formation of a cricket team and the coming together of villagers in challenging the whites, "the other," create a sense of belonging and togetherness that is voiced by the determination of villagers to change their fate by removing the oppression of the "white" ruler. Lagaan also speaks of many "others" such as the white outsiders (British soldiers), the other racial whites (the representatives of the British East India Company), the Raja (the feudal lord of the area), the white sympathetic lady among the villagers (sister of Russell), the marginalized group (the villagers), the other gender (women), faith based individuals (Muslim and Sikh), and the untouchable. It is a combination of complex relationships brought together in an imagined society that thrives in order to protect its right.

Lagaan shows how a popular sport/culture unites the whole community of the village. In terms of their own survival and upholding the identity of the villagers of Champaner as well as the whole state, cricket became an instrument for mobilizing vast populations and national sentiments. Bhuvan repeatedly speaks of contentious issues regarding British rule, the feudal administration, colonialism, racism and brutality.

Similarly Sarfarosh (1999) reflects issues of identity, nation formation, mistrust, legacy of partition, suspicion and the conflicting Indo-Pak relationship while examining Muslim identity in a post-partition India and South Asia. The film was released at a time when India was agitated by Pakistan's war on the Mountain of Kargil in the Kargil district of Kashmir between May and July 1999. Critics termed the film "a timely comment on Pak-sponsored terrorism India." ${ }^{13}$ The Indian government withdrew an entertainment tax for three months in an attempt to bolster the image of the Indian Army and Air Force operations that literally foiled the Pak-sponsored 
infiltrations (as India claims the Inter-Services Intelligence (ISI) of Pakistan is always behind such atrocities). ${ }^{14}$

Sarfarosh tells a story of conflicting ideologies of identity, and how Pakistani intelligence (ISI) recruits Muslim people from India to create instability within the territory of the country. The film discusses how, on one occasion, a Pakistani top military official is ordered to carry out a proxy-war in India. It shows how Muslims fleeing India during the partition were forced to find a place to live, while refusing to identify as members of the Pakistani nation. In the film, those who left India for Pakistan 50 years after independence are still regarded as refugees (muhajir). Even Muslims who left Pakistan for India are misunderstood, particularly over their faith and beliefs. They are either judged by Indian Hindus to be Pakistani agents or treated as second class citizens within their ancestral homeland.

In the film, Inspector Salim (Mukesh Rishi) is a Muslim police officer who is scrutinized and surveilled by his co-workers. The police department suspects Salim has been siding with Muslim criminals. His "Muslimness" is a fundamental question and concern in the film. Inspector Salim loses his courage and complains to the Assistant Commissioner of Police (ACP) Ajay Singh Rathod (Aamir Khan), a middle class Hindu, and asks to have his name removed from the investigation. Salim comments harshly: "It is a sin to be poor in this country (India) and to be a poor individual like me is also a great sin." Thus Salim believes he is being treated unfairly and discriminated against due to his race and faith.

When Salim hands over the case to the ACP Rathod, he narrates to Salim the brutality and cruelty he and his family faced and how these experiences led him to become a police officer. Here, Rathod "articulates predicament as being not discrimination—a systematic problem—but rather about belonging — an existential problem." 15 
The following dialogue between Rathod and Salim is significant:

Rathod: The reason behind telling you all this is not that I am concerned with my home, not at all-but I am concerned with my country (yeh meray mulk ka muamela hai).

Salim: What, these are not related to my country too?

Rathod: Maybe not. That's the reason you're running away from your duties. I consider my country as my home and I don't need any Salim to save my country.

Salim: Go and save your country and save your own home. What necessity of me is there then?

Rathod: No, I really need Salim. I need not only one Salim but ten Salims to save this home (country).

Salim: Not only ten, you will find ten thousand if you can trust them. Don't ever try to say to anybody that this country is not his home (or does not belong to him).

Rathod: I will never say it. I will never.

\section{(Translated from Hindi by the author)}

The conversation between the two police officers is very symbolic in the film. Both share a love for the homeland, and are determined to save the country from any wrongdoing by perpetrators. But both are viewed by society as being different in identity and faith. That's why Rathod repeatedly tries to prove that Salim genuinely loves his country and his roots in India. Rathod manipulates Salim's Muslim identity, and subsequently reminds him that India is not his country by repeating "maybe not." It may be noted here that all Muslims in India face allegations from various quarters of society as the partition implanted an imagined Muslim identity in the minds of hundreds and thousands of Hindus in India.

The film depicts an infiltration of arms and ammunition from Pakistan by the direction of the ISI across the Indian border, near the Thar Desert of Rajasthan, India. Bala Thakur, a criminal 
and gun-seller, delivers the arms and ammunitions to Veeran, a forest tribal leader who wants to establish his own rule and hegemony in the region. He along with his gang looted and massacred a wedding bus at Chandrapur to destabilize the country, and the political elites assigned the investigation to the Mumbai Police Crime Branch. ACP Rathod searches for links between the underground Mafia sects (and other hostile organizations), the gun-business, local criminal gangs and the Chandrapur massacre.

The characters in the film, especially ACP Rathod, Police Inspector Salim, singer Gulfam, businessman Haji and gang member Sultan use the words quam (community/ethnic group), mulk (country) and ghar (home) repeatedly and these words have specific connotations. "Qaum can be translated as nation, a people, a race, tribe or sect, and it can be used for a nonterritorial identity, such as in this case, the Muslim quam." ${ }^{16}$ Haji does not recognize the land of India as his mulk (country) but constantly identifies himself as being part of qaum (community). He often says the word qaum (i.e. Muslim community) while talking to Salim in the mosque, and Salim rejects the identity of the Muslim community and utters boldly in Hindi: mai tumhare tarha nahin hoon (I am not like you guys). Salim prefers to use the word 'country' (India) as a whole, rather than community (in a narrow sense) and believes in a pluralistic society. On the contrary, Haji is determined and seems happy to be identified as a member of the Muslim community. His belief in mulk is very fragile and he works against the country by smuggling arms and ammunition supplied by the ISI. Salim, an honest police officer, prefers his own ethics and is guided by the spirit of nationalism and a greater unity between different communities, tribes and religious factions.

The film shows that quam and mulk are different in meaning and connotation; mulk is a sovereign and territorial entity and quam is a non-territorial identity. ACP Rathod and Inspector 
Salim emphasize a modern India of different sub-nations and communities and advocate for a modern and secular India. On the flip side Gulfam, Haji and Sultan struggle against Indian modernity and secular trends by creating an atmosphere of confusion in the democratic land. The partition has divided family and kinship; Sultan, Haji, Gulfam and others' homes are in India and Pakistan. Their identity is divided, as are notions of home and hearth because their relatives are in Pakistan so they are treated unfairly in India. As Fazila-Yacoobali rightly puts, "Sarfarosh makes a lesson of distinguishing Pakistan as not a 'homeland' for all Muslims. Countering chants like Jao Pakistan ya Kabarasthan (Go to Pakistan or to your grave)... is emphatic that there is no Pakistan for Muslims of India to go to." ${ }^{17}$ When Inspector Salim is relieved of his responsibilities, it is an example of suspicion and doubt seeping into the imagination of Indian society. He simply contends:

Es Muluk me garib hona ek gunah hai aur garib mujh jeisa aur bhi bara gunag hai (It is a great sin to be poor and to be a poor person like me is the greatest sin).

Salim chose to be a police officer in the city for his and his family's well-being and security (the film didn't mention anything about his family), but he is discriminated against and scrutinized by senior officers at the department. He is sincere and devoted to his duties in all aspects and chases criminals who happen to be fellow Muslims. Thus, he prefers to be a true Indian rather than a Muslim. His nationalistic outlook is not properly valued by the police department, and the Gandhian philosophy of Ahimsa (as Indian values...do not harm or kindness towards all) is ignored in the case of Salim who represents the Muslim community. 


\section{The Other-Muslims, Christians, Sikhs and Parsis: the Marginalized and the Demonized}

As a nation, India has been thriving to define its identity in the post-colonial era as a secular, multiethnic, diverse and pluralistic society despite the following majors events: the demolishment of the Babri Mosque and killing of the Muslim People in Gujarat in 1992 and the killing of members of the Sikh minority, especially in New Delhi, after the assassination of former Prime Minister Indira Gandhi in 1984. However, some critics like Khilnani boast about India's distinct quality and particular characterization, including its strength exemplified in its ability "to transform invasion into accommodation, rupture into continuity, division into diversity." 18 According to a report released by the National Integration Council of India (2005), between 2000 and 2005 India experienced an annual average of 800 incidents of various types ranging from bullying and local clashes to full-scale riots, such as the one in Gujarat in 2000 that resulted in the death, destruction and widespread displacement of hundreds and thousands of Muslims under the shadow of ethnic cleansing. ${ }^{19}$

Such coercive actions against ethnicity have reasonably undermined India's cautiously constructed concept of identity, pluralism and secularism that originated in the postcolonial state under the leadership of Nehru, the former prime minister of India. Despite flourishing into a modern India, since the 1990s radical Hinduism or Hindutva has divided the nation over specific issues and its influence manifests in a number of social and political institutions. $^{20}$ Bollywood is often considered to be the social microcosm of India where Hindus, Muslims and Christians work in an industry that produces 150 to 200 films per year. ${ }^{21}$ In the Bollywood industry "not only [are] Muslims comparatively well-represented within its ranks and in the form of writers, lyricists, composers, and directors, but... some of the most popular film stars of Hindi cinema, both male and female, have been Muslim." 22 
Although Muslims dominate Hindi films in various aspects including acting, the industry is one of few institutions in India where they enjoy some success and popularity. ${ }^{23}$ In some commercial Hindi movies Muslims are portrayed as 'the Other' and the cinematic Othering of Muslims "has occurred through a variety of strategies of representation ranging from exoticization and marginalization to demonization, that are widely recognized by anthropologists as critical to the production and maintenance of social and cultural difference." ${ }^{24}$ For the last fifty years Hindi cinema has portrayed the Muslim community as exotic, marginalized and demonized because it represents ultra-nationalistic attitudes, depicting the Mughal rulers as invaders before the British came to the power. Even the pre and post-independence periods (1940s to 1960s) of Hindi cinema portrayed Muslims as the exotic other, such as Pukar (1939), Tansen (1944), Humayun (1945), Shahjehan (1946), Baiju Bawara (1952), Anarkali (1953), Mirza Ghalib (1954), Jahan Ara (1964), Noorjehan (1967), and Mughal-e- Azam (1960). The stories in these films are mainly related to the Mughal Empire. These films depict the lavish life, mannerisms and etiquette of the Muslim Mughal court aristocracy, representing "Muslims only as members of the ruling class who generally spoke, dressed, and behaved differently from the norm, they rendered them a group distinct and separate from the mainstream.” 25

A thematic shift occurred in Hindi cinema during the 1970s and 1980s when the casting of Muslim characters in film was limited; thus a trend of marginalization emerged in relation to the Muslim community. The films represent Muslim characters in certain stereotypic occupations such as tailors, qawali singers, uncles, quack doctors (practitioners of traditional herbal medicine), family friends, temple-men, counselors and labourers. They wear certain kinds of outfits which are prominent, recognizable and identifiable. For example, Pran in Zanjeer (1973) is a typical Muslim with henna-dyed hair and wearing a Salwar Kameez (a dress like pajama and 
girl's top); Rishi Kapoor in Amar Akbar Anthony (1977) is a qawali singer and Amitabh Bachan in Coolie (1983) wears number " 786 " on his shirt, a number that is very precious and sacred to the Muslim community [this numerological number is the combination of a few Arabic words used to admire the Creator (Allah)].

Throughout the 1970s and 1980s, when the campaign of BJP against Muslims and in favour of Hindutva shook the entire country, Indian cinema began depicting stereotypical Muslim characters and ignored their social status and ethos; even the secular image of India disappeared from storylines. Kazmi rightly says:

"the characterization of Muslims is delineated in terms of abstractions. They emerge as stereotypes represented by well-defined signs of speech, appearance, dress, social and religious practice...ignored are the real life [of] men and women with distinct class positions, social backgrounds and individual dispositions." ${ }^{26}$

Indian movies of the 1990s and 2000s emerged as nationalistic in nature, as Salam (2005) mentions "in the shadow of saffron" [a party colour of the BJP, a fundamentalist party who came to the power in India in 2014]. In the majority of box-office hits, Muslim characters appear as the antagonists by engaging in conspiracies with outsiders and especially with Pakistan; hatching terrorist plots on Indian soil; running mafia rings or as underground dons in the city or working with hit men, demolishing slums and generally creating chaos in the city. For example, the following movies portray Muslims in a negative way: as criminals in Farz (2001) and Angaar (1992), corrupt and immoral power-hungry politicians in Bas Itna sa Khawab hai (2001), misguided and corrupt police personnel in Shool (1999), villains in Love Ke Liye Kuch bhi Karega (2001), and brutal Pakistani attackers in Border (1997) and LoC Kargil (2003). These films resonate with Hindutva through masculine and anti-Pakistani sentiments. 
Sarfarosh, Mission Kashmir and Ma Tujeh Salaam (2002) are films where Muslim characters are determined to show their loyalty to India; even the good and honest Muslim alBaksh dies as a martyr in Ma Tujeh Salaam. It is not only Muslim characters that are suppressed in Indian movies but other protagonists of Christian, Sikh and Parsi faiths are also being portrayed in a typical manner. Christian characters often appear as drunken, addicted and sick, and names like Robert and Michael are generally given to male characters whereas dancers, bad girls and prostitutes are often named Mona and Lilly. Sikh characters are also presented as illogical and shortsighted and Parsis are depicted as absent-minded buffoons, "while Muslims have been variously exoticized, marginalized, and demonized within the master narrative of commercial Hindi films." 27

\section{Bollywood and the Hegemonic Role}

Of late, the hegemonic role of Bollywood cannot be ignored. Bollywood provides narratives with socio-political messages, and not just for viewing audiences as they generate discourses for political, intellectual, social, academic and media elites as well. Such messages are rooted in political narratives aimed at the vast majority of the population while targeting political elites as they develop their political agenda. Thus films play a greater role in working as a catalyst inside and outside of India. As such "Bollywood productions have increasingly been seen as iconic of India's global ambitions, and described as major source of cultural capital in the mediation of the global." 28

The majority of Indian films are not based on Indian culture as they "continue to lend and borrow motifs from other cultures, both proximate and exotic. This is indicative, perhaps, of a different notion of how culture works" in Indian cinema. ${ }^{29}$ Various genres of Indian film can 
have a significant impact on governments, political gurus, media moguls, academics, researchers and above all the mass population of the region. This popular media has reached all sections of society in South Asia including politicians, corporate elites, NGOs, academics, bureaucrats and younger generations. Viewers watching the films in the region are connected through the formation of geopolitical imaginations, transborder values and reconciliation.

Throughout the region, Bollywood movies offer their audiences an interpretation of culture, rituals, nation-formation, danger, threats, suspicion and messages of identity. Most of the governments of India have tried to influence Bollywood and if we look at the trajectory of the last two decades, the right wing ruling Bhartiya Janata Party government in 1998-2004 capitalized on Bollywood fame by proclaiming it "a transmitter of timeless Hindu values" while the Congress Party regarded Indian film as “a modern avatar of India's rich syncretic culture." ${ }^{30}$ Former Indian Prime Minister Manmohan Singh claimed on September 26, 2007:

"No other institution has been as successful in achieving the emotional integration of this vast and diverse land of ours as our film industry has been...This unique mix of conversational Hindi from across the country, popularized by the film industry, has become the thread that weaves us all together as Indians." 31

In the late 1990 s and in the early decade of this century, J.P. Dutta's trilogy Border (1997), Refugee (2000) and LOC Kargil War (2003) epitomized the Indian version of war, specifically through the depiction of political rhetoric by the BJP, the military-buildup of both India and Pakistan, the Kashmir crisis and terrorism. ${ }^{32}$ Through Border and Refugee, Dutta, as he claims, promotes a message of peace between India and Pakistan, although the film Border provoked anger in Muslim communities at home and abroad due to what many perceived to be a violation and misrepresentation of Muslim faith and religion. Dutta notes however that he was 
"trying to tackle a serious bilateral issue here. At least I have the guts to bring up such a sensitive subject in a mainstream Hindi film." 33

Bollywood's engagement at home and abroad and especially in the region is remarkable. It not only connects with upper middle class, middle class, lower middle class families and mass population as a whole but its messages simultaneously reach the political elites and bureaucrats who design strategy for foreign policy and regional relations. Rahimulla Yusufzai's words can be mentioned here:

"the popularity of Indian films like Roja, Border, Mission Kashmir and Refugee in the Paksiatni home video market. These films which depict the Indian view of Kashmir Issue, are being secretly rented after a ban by the government...Video stores in Islamabad [of Pakistan] report brisk demand for Bollywood films, including the 'anti-Pakistani' ones.” 34

Other movies, such as Slumdog Millionaire (2008) are worthy of mention here. The film, directed by British filmmaker Danny Boyle recounts the story of a penniless Mumbai slum boy. The film received 10 Academy Awards and was well received around the world.

\section{Conclusion}

These three films mainly depict India's integrity and nationalistic outlook but the notion of duty, obligation and reconciliation - a universal philosophy in which Gandhi of India firmly believed - is somehow missing from the core messages disseminated to the audience. They depict many characteristics of the sub-continent, especially its people and politics. Earth, Lagaan and Sarfarosh are not only a form of entertainment but a vocal media for contestation around geopolitical meaning and discourse. 
Narratives produced by Bollywood clearly have a tremendous impact in terms of audience and revenue generation. There exist a number of examples in which governments and political elites have used films to manipulate public opinion to construct discourses and narratives, especially during periods of war and crisis in India. As I mentioned earlier, Sarfarosh, released in 1999 after the Kargil War, is a good example of such manipulation. The government even removed taxes on movie ticket sales in order to attract the public to the film and as an attempt to justify the loss of soldiers and funds invested in the war.

Words like quam (nation), muluk (country), ghar (home) and community in the films work to construct an identity and a unified platform of different religions while acknowledging the ways in which human beliefs can influence and transform communities toward a better society. The wretched depiction of Others (Muslims, Christians, Sikhs and Backward classes) who struggled since independence in 1947 are highlighted in the films, only to be branded as traitors, invaders and fools while being deprived most of the civic services available in Indian society. Various sections such as Muslims in India and Hindus, Sikhs and Christians in Pakistan have been struggling for their identity and they are segregated as minorities into their ancestral homelands demarcated and constructed by 'other' and the colonizer. Earth, Lagaan and Sarfarosh depict representations of mistrust, hatred, suspicion and insecurity, which have become an integral part of societal norms and politics in India. These three films construct geopolitical images of identity, belonging and difference emphasizing that while Hindus and Muslims are Indians some legacies and sufferings brought on by the partition of British India still resurrect in memories when discrimination and exclusion are practiced. 


\section{BIBLIOGRAPHY}

Athique, Adrian. 2011. "Diasporic Audiences and Non-Resident Media: The Case of Indian Films," Participations (Journal of Audience and Reception Studies), Vol. 8(2), pp. 1-23.

Basu, Anustup.2010. Bollywood in the Age of New Media, Edinburgh University Press.

Bhabha, Homi.1994. The Location of Culture, Routledge.

Chadha, Kalyani and Kavoori, Anandam P. 2008. "Exoticized, Marginalized, Demonized: The Muslim “Other” in Indian Cinema,” Global Bollywood, pp. 131-145.

Chakraborty, Chandrima.2004. "Bollywood motifs: Cricket fiction and fictional cricket," International Journal of the History of Sport, Vol. 21 (3/4), pp. 549-572.

Das, A.1999. "Kargil or not, Sarfarosh stands alone: Amir Khan,” Express Newsline, May 31, pp. 4.

Desai, Jigna and Dudrah, Rajinder.2008. “The essential Bollywood,” In Rajinder Dudrah and Jinga Desai (eds.) The Bollywood Reader, Open University Press.

Fazila-Yacoobali, Vazira.2002. "Yeh mulk hamara ghar: the 'national order of things' and Muslim identity in John Mathew Mattan's Sarfarosh," Contemporary South Asia, Vol. 11(2), pp. 183-198.

Film4.com. "50 Films To See Before You Die,” http://www.film4.com/special-features/toplists/top-50-films-to-see-before-you-die, [Accessed on 15th of August, 2015].

Ganti, Tejaswini.2004. Bollywood. A Guidebook to Popular Hindi Cinema, London, Routledge. 
Gregory, Derek.2004. The Colonial Present: Afghanistan, Palestine, Iraq, Blackwell, Malden, MA.

Gulzar, Nihalani Govind and Chatterji, Saibal.2003. Encyclopedia of Hindi Cinema, Encyclopedia Britannica (India) Pvt. Ltd., pp. 136-137.

Kazmi, F.1994. "Muslim Socials and Female Protagonist: Seeing a dominant Discourse at Work," In Z. Hazan (ed.) Forging Identities, Gender, Communities and the State, New Delhi, Kali for Women, pp. 226-43.

Khilnani, S.1997. The Idea of India, London, Penguin Books.

Lichtner, Giacomo and Bandyopadhya, Sekhar. 2008. "Indian Cinema and the Presentist Use of History," Asian Survey, Vol. 48(3), pp. 431-452.

Pauwels, Heidi. 2007. Indian Literature and Popular Cinema: recasting classics, Routledge.

The Hindustan Times (New Delhi).1999. "Sarfarosh is tax free”, 6 June, pp. 1.

\section{ENDNOTES}

\footnotetext{
${ }^{1}$ Nihalani Govind Gulzar and Saibal Chatterji, Encyclopedia of Hindi Cinema, Encyclopedia Britannica (India) Pvt. Ltd., 2003, pp. 136-137.

${ }^{2}$ Heidi Pauwels, Indian Literature and Popular Cinema: recasting classics, 2007, Routledge.

${ }^{3}$ Ibid.

${ }^{4}$ Ibid., pp. 50.

${ }^{5}$ Jigna Desai and Rajinder Dudrah, “The essential Bollywood,” In Rajinder Dudrah and Jinga Desai (eds.) The Bollywood reader, Open University Press, 2008, pp.13.

${ }^{6}$ Ibid., pp. 13.

${ }^{7}$ Giacomo Lichtner and Sekhar Bandyopadhya, "Indian Cinema and the Presentist Use of History," Asian Survey, Vol. 48(3), 2008, pp. 437.
} 
${ }^{8}$ Derek Gregory, The Colonial Present: Afghanistan, Palestine, Iraq, Blackwell, Malden, MA, 2004.

${ }^{9}$ Homi Bhabha, The Location of Culture, Routledge, 1994, pp. 63.

${ }^{10}$ Giacomo Lichtner and Sekhar Bandyopadhya, "Indian Cinema and the Presentist Use of History," Asian Survey, Vol. 48(3), 2008, pp. 441.

11 Film4.com, "50 Films To See Before You Die," Accessed on 15 $5^{\text {th }}$ of August, 2015: http://www.film4.com/special-features/top-lists/top-50-films-to-see-before-you-die

${ }^{12}$ Chandrima Chakraborty, "Bollywood motifs: Cricket fiction and fictional cricket," International Journal of the History of Sport, Vol. 21 (3/4), 2004, pp. 557.

${ }^{13}$ Das, A. "Kargil or not, Sarfarosh stands alone: Amir Khan," Express Newsline, May 31, 1999, pp. 4.

${ }^{14}$ The Hindustan Times (New Delhi), "Sarfarosh is tax free," 6 June, 1999, pp. 1.

${ }^{15}$ Vazira Fazila-Yacoobali, "Yeh mulk hamara ghar: the 'national order of things' and Muslim identity in John Mathew Mattan’s Sarfarosh,” Contemporary South Asia, Vol. 11 (2), 2002, pp. 185.

${ }^{16}$ Ibid., pp. 188.

${ }^{17}$ Ibid., pp. 197.

${ }^{18}$ S. Khilnani, The Idea of India, London: Penguin Books, 1997, pp. xvi.

${ }^{19}$ Kalyani Chadha and Anandam P. Kavoori,"Exoticized, Marginalized, Demonized: The Muslim "Other" in Indian Cinema," Global Bollywood, 2008, pp. 132.

${ }^{20}$ Ibid., pp. 132.

${ }^{21}$ Ibid.

${ }^{22}$ Ibid., pp.133 \& Tejaswini Ganti, Bollywood. A Guidebook to Popular Hindi Cinema, London, Routledge, 2004, pp. 23.

${ }^{23}$ Ibid., pp. 24

${ }^{24}$ Kalyani Chadha and Anandam P. Kavoori,"Exoticized, Marginalized, Demonized: The Muslim "Other" in Indian Cinema," Global Bollywood, 2008, pp. 134.

${ }^{25}$ Ibid., pp. 136.

${ }^{26}$ F. Kazmi, "Muslim Socials and Female Protagonist: Seeing a dominant Discourse at Work," In Z. Hazan (ed.) Forging Identities, Gender, Communities and the State, New Delhi, Kali for Women, 1994, pp. 230-40.

${ }^{27}$ Kalyani Chadha and Anandam P. Kavoori, "Exoticized, Marginalized, Demonized: The Muslim "Other" in Indian Cinema," Global Bollywood, 2008, pp. 143.

28 Adrian Athique, "Diasporic Audiences and Non-Resident Media: The Case of Indian Films," Participations (Journal of Audience and Reception Studies), Vol. 8(2), 2011, pp. 6.

${ }^{29}$ Ibid., pp. 17. 
30 Ibid.

${ }^{31}$ Ibid., pp. 8 .

${ }^{32}$ Adrian Athique, "A Line in the Sand: The India-Pakistan Border in the Films of J.P. Dutta," South Asia: Journal of South Asian Studies, Vol. 31(3), 2008, pp. 472-499.

33 Ibid., pp. 496.

${ }^{34}$ Ibid., pp. 497-98. 